\title{
Investigating the effect of fructose on glucose, insulin, adiponectin, leptin and triglyceride tolerance in adult laboratory rats
}

\section{CBesim Memedi ${ }^{*}$, DAgron Zuferi ${ }^{2}$}

State University of Tetova, Tetovo, North Macedonia ${ }^{2}$ General Hospital "Ferid Murad" Gostivar, Gostivar, North Macedonia
RECEIVED:

December 10, 2020

ACCEPTED:

December 18, 2020

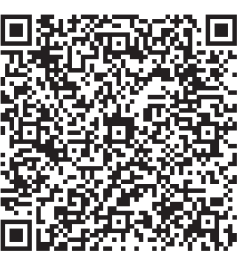

KEYWORDS: fructose, obesity, insulin resistance

CITATION: Cardiol Croat. 2021;16(1-2):37. | https://doi.org/10.15836/ccar2021.37

*ADDRESS FOR CORRESPONDENCE: Besim Memedi, State University of Tetova, St. Ilinden bb 1200, 1220 Tetovo, North Macedonia. / Phone: +389-70571032 / E-mail: besim_memedi@hotmail.com

ORCID: Besimk Memedi, https://orcid.org/0000-0002-2383-5452 • Agron Zuferi, https://orcid.org/0000-0002-1038-1519

IIIIIIIIIIIIIIIIIIIIIIIIIIIIIIIIIIIIIIIIIIIIIIIIIIIIIIIIIIIIIIIIIIIIIIIIIIIIIIIIIIIIIIIIIIIIIIIIIIIIIIIIIIIII

Introduction: The metabolic syndrome over recent years is being actively studied and is in the focus of experimental and clinical studies. Insulin resistance cause major problem in metabolism and is related not only to obesity but also to the pathogenesis of type 2 diabetes, cardiovascular disease, etc..$^{1-3}$ Purpose: The effect of fructose on body weight in experimental adult rats and the effect of fructose on the content of glucose, triglycerides, uric acid, insulin, adiponectin and leptin in the blood of experimental animals

Material and Methods: The study was performed on 12 adult male rats divided into two groups: control group and fructose group. Experimental animals were treated daily in a period of 8 weeks with 10\% fructose solution, $1 \mathrm{ml} / 100 \mathrm{~g}$ by mouth (per os). While, the control group of animals was treated with a vehiculum (physiological digestion)

Results: Table 1 are presented the changes in body weight of experimental animals under the influence of fructose. Statistically significant $(p<0.05)$ is the weight of fructose-treated experimental animals compared to the control group at the end of the experiment. Table $\mathbf{2}$ presents the results from the definition of other indicators. The animal blood glucose levels are elevated treated with glucose compared to the control group. Statistically significant is the increase in blood of the triglyceride levels after 8 weeks of glucose treatment.

Conclusions: The analysis of insulin elevation and blood sugar rise gives us reasons for the development of "insulin resistance" under the influence of fructose. At the experimental animals cannot be demonstrated the effect of insulin elevation, and fasting blood sugar is elevated after 8-week treatment with fructose.

TABLE 1. Influence of fructose on body weight of adult male mice.

\begin{tabular}{lcc}
\hline Group & Weight at the beginning of the experiment $(\mathbf{g})$ & Weight at the end of the experiment $(\mathbf{g})$ \\
\hline $\mathrm{K}(\mathrm{n}=6)$ & $130.0 \pm 30.0$ & $180.0 \pm 33.0$ \\
\hline$H(n=6)$ & $132.0 \pm 25.0$ & $250.0 \pm 40.0^{*}$ \\
\hline
\end{tabular}

TABLE 2. Impact of fructose on glucose, triglyceride, uric acid, insulin, adiponectin and leptin contents in experimental animal blood.

\begin{tabular}{lcccccc}
\hline Group & $\begin{array}{c}\text { Glucose } \\
(\mathbf{m m o l} / \mathrm{L})\end{array}$ & $\begin{array}{c}\text { Triglycerides } \\
(\mathbf{m m o l} / \mathrm{L})\end{array}$ & $\begin{array}{c}\text { Uric acid } \\
(\mathbf{m g} / \mathbf{d L})\end{array}$ & $\begin{array}{c}\text { Insulin } \\
(\mathrm{ng} / \mathrm{ml})\end{array}$ & $\begin{array}{c}\text { Adiponektin } \\
(\mathbf{n g} / \mathbf{m l})\end{array}$ & $\begin{array}{c}\text { Leptin } \\
(\mathbf{n g} / \mathbf{m l})\end{array}$ \\
\hline $\mathrm{K}(\mathrm{n}=6)$ & $6.0 \pm 0.4$ & $1.2 \pm 0.03$ & $3.7 \pm 0.2$ & $2.8 \pm 0.3$ & $6.0 \pm 2.1$ & $28.7 \pm 3.1$ \\
\hline $\mathrm{H}(\mathrm{n}=6)$ & $18.2 \pm 1.2^{\star}$ & $4.6 \pm 0.3^{*}$ & $6.5 \pm 1.1^{\star}$ & $3.5 \pm 1.8^{*}$ & $2.4 \pm 0.05^{\star}$ & $35.9 \pm 4.0^{\star}$ \\
\hline
\end{tabular}

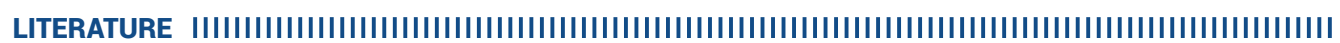

1. Reaven GM. Insulin resistance and human disease: a short history. J Basic Clin Physiol Pharmacol. 1998;9(2-4):387-406. https://doi.org/10.1515/JBCPP.1998.9.2-4.387

2. Alberti KG, Zimmet PZ. Definition, diagnosis and classification of diabetes mellitus and its complications. Part 1: diagnosis and classification of diabetes mellitus provisional report of a WHO consultation. Diabet Med. 1998 Jul;15(7):539-53. https://doi.org/10.1002/(SICI)1096-9136(199807)15:7<539::AID-DIA668>3.0.C0;2-S

3. Meerson A, Traurig M, Ossowski V, Fleming JM, Mullins M, Baier LJ. Human adipose microRNA-221 is upregulated in obesity and affects fat metabolism downstream of leptin and TNF-a. Diabetologia. 2013 Sep;56(9):1971-9. https://doi.org/10.1007/s00125-013-2950-9 